\title{
Good Corporate Governance And Corporate Social Responsibility In Moderating The Effect Of Environmental Performance On Financial Performance
}

\author{
Koko Safitri \\ Sampit College Of Economics, South Kalimantan, Indonesia. \\ ${ }^{*}$ Corresponding Author: \\ Email: kokosafitri@gmail.com
}

\begin{abstract}
.
The purpose of this study was to determine how much influence environmental performance has on financial performance and the influence of Good Corporate Governance and Corporate Social Responsibility on companies listed on IDX30 for the period February - April 2021. By using a descriptive approach and the SEM-PLS method. This research was conducted by taking secondary data. Sources of data were obtained from the annual report published on the Indonesia Stock Exchange (IDX) in 2019 on the website (www.idx.co.id) and the CPRP report issued by the Ministry of Environment and Forestry in 2018-2019. The results showed that; (1) Environmental performance has an effect on financial performance, with $P$ Values of $0.023<0.05$. (2) Good Corporate Governance does not moderate the relationship between environmental performance and financial performance, with $P$ Values of $0.196>0.05$. (3) Corporate Social Responsibility as a moderator of the relationship between environmental performance and financial performance, with $P$ Values of 0.024 $<0.05$.
\end{abstract}

Keywords: Environmental Performance, Financial Performance, GCG, CSR

\section{INTRODUCTION}

The Corporate Performance Rating Program is a program initiated by the Ministry of Environment since 1995 to encourage companies to manage their surrounding environment. The creation of the Company Performance Rating Assessment Program is due to awareness regarding the company's operations in their activities that can have an impact on the environment and community expectations so that the company can control activities that can have a major impact on people's lives. Various industrial problems such as natural damage due to excessive exploitation of nature but not balanced with environmental improvements or damage to the natural balance such as pollution and factory waste are very detrimental to the surrounding environment. The Corporate Performance Rating Program creates an image for companies according to how they manage their environment. The image rating is assessed by color ratings such as gold, green, blue, red and black. The brighter the color of the assessment given, the better the company in managing its environment, such as the gold color which is the best CPRP rating, which means that the company 
has implemented good and sustainable environmental management. The company pays attention to the environment as a form of corporate responsibility and concern for the environment [1]. The better the environmental activities of a company, it can increase trust among stakeholders so that it has an impact on financial performance.

In achieving the rating of the Corporate Performance Rating Program, it cannot be separated from good corporate governance which can be called Good Corporate Governance (GCG). Sulistyanto [2] states, definitively good corporate governance is defined as a system that regulates and controls the company so that the company creates added value for all stakeholders. If the rating of a company's Corporate Performance Rating Program is good, then there is an indication that its corporate governance will also have a good impact in accordance with management mechanisms based on laws and corporate ethics. The principle of implementing GCG has an impact on improving the company's performance and economic value in the long term for interested parties such as investors and stakeholders. The implementation of GCG includes several things such as ethical behavior guidelines, information and technology governance, reporting mechanisms related to alleged irregularities, as well as internal control and supervision systems. If the governance of a company is not good, the company's operating activities related to financial performance will also not run well $[29 ; 30 ; 31 ; 32]$. In addition to being related to Good Corporate Governance, environmental performance also has an influence on Corporate Social Governance (CSR). Corporate Social Responsibility is the transparency of social disclosures originating from social activities and activities carried out by the company in the form of a commitment to account for the impact of the company's activities to its stakeholders. Transparency in disclosing information about social and environmental impacts caused by company activities is also no less important than disclosing company financial information because success in managing environmental performance really requires CSR as a supporter of successful environmental performance which can indirectly have an impact on company financial performance in terms of earn profit.

Company performance is influenced by various forms of social responsibility. Corporate decision makers must consider various social and environmental issues if they are to maximize long-term profits [2]. A concern for the community by holding CSR from internal companies will provide a good image for the company in the long term. Corporate Social Responsibility will have a good impact on the company's financial performance as long as it is in accordance with the company's capabilities and makes it a must for companies whose financial conditions are considered healthy [26; 27; 28]. A concern for the community by holding CSR from internal companies will provide a good image for the company in the long term. Corporate Social Responsibility will have a good impact on the company's financial performance as long as it is in accordance with the company's capabilities and makes it a must for companies whose financial conditions are considered healthy $[26 ; 27 ; 28]$. A concern 
for the community by holding CSR from internal companies will provide a good image for the company in the long term. Corporate Social Responsibility will have a good impact on the company's financial performance as long as it is in accordance with the company's capabilities and makes it a must for companies whose financial conditions are considered healthy $[26 ; 27 ; 28]$.Environmental performance is in dire need of instruments such as Good Corporate Governance (GCG) and Corporate Social Responsibility (CSR) in its operations so that it can run optimally to get an advantage that affects the company's financial performance. Good and bad financial performance depends on the policy of the company's leadership in paying attention to the company's financial performance where an assessment of performance is very necessary to make good and directed decisions, as Pujasih [3] opinion states that the assessment of a company's performance or performance is measured because can be used as a basis for decision making both internal and external parties. Each company has a different environmental performance depending on how much attention the company has to the environment, especially the surrounding environment.

The author uses a manufacturing company in IDX30 for the period February April 2021 which is listed in the amendment to the Decree of the Minister of Environment and Forestry Number SK.1049/MENLHK/SETJEN/PKL.4/12/2019 concerning the Results of the Assessment of Company Performance Ratings in Environmental Management in 2018 -2019 as the object of research to see how much influence this has on manufacturing companies listed in index 30 that have high liquidity criteria, large market capitalization, and are supported by good company fundamentals. According to Hery [4], The definition of liquidity is the ability of a company to pay short-term obligations (debt) on time including paying off long-term debt that matures in the year concerned, meaning that a company that has high liquidity is a company that has a good level of ability to pay short-term debt or obligations. whose due date is near. Market capitalization or market value is determined by the demand and supply of the shares concerned in the stock market [5;32;33], means that the company that has a large market capitalization is a company that has the number of values of all outstanding shares rated high because it has high volume demand. According to the stockmilenial.com criteria company has a good fundamental is a company that has a market capitalization of more than Rp. 500 billion, it is easy to rebound after the stock correction, the company's business model is clear, the company's products are often encountered, and the occurrence of increased profit in each quarter.Based on this explanation, the authors conducted research on the Effect of Environmental Performance on Financial Performance through Good Corporate Governance and Corporate Social Responsibility where environmental performance is used as the independent variable, financial performance as the dependent variable, and Good Corporate Governance and Corporate Social Responsibility as the connecting variable or moderator. 


\section{LITERATURE REVIEW}

The theoretical foundation is one of the parts in a study that contains theories and research results derived from literature studies. This section serves as the theoretical framework used to complete various research work. The preparation of a good and correct theoretical basis in a research is important because the theoretical basis is the foundation and foundation of the research.

\section{Environmental Performance}

Environmental performance is a company's performance that focuses on company activities in preserving the environment and reducing environmental impacts arising from company activities [6]. Meanwhile, according to Suratno [7] environmental performance is the company's performance in creating a good (green) environment.Thus, environmental performance is a company's performance that focuses on company activities in preserving the environment and reducing environmental impacts arising from company activities. The company pays attention to the environment as a form of corporate responsibility and concern for the environment [1]. The community living around the company has an interest in the social and environmental impacts that come from the company's activities [8].Pflieger's research [9], shows that environmental conservation efforts by companies will provide a number of benefits, including the interests of shareholders and stakeholders in corporate profits caused by responsible environmental management according to public perception. Other studies have shown that good environmental management can avoid claims by the community and the government as well as improve product quality so as to increase the company's financial profit. The company's awareness of determining good environmental performance is actually a manifestation as well as a meeting point between the interests of corporate ethical actors and the essence of a sustainable development strategy, namely through integrating economic, social, community and environmental development.

Environmental performance in this study was measured using the Company's Performance Rating Program in Environmental Management. The Corporate Performance Rating Program is an assessment of the environmental management performance of a company that requires measurable indicators. This is what the Ministry of Environment of the Republic of Indonesia has implemented with the aim of increasing the role of companies in environmental management while at the same time creating a stimulant effect in compliance with environmental regulations and adding value to the maintenance of natural resources, energy conservation, and community development. After the enactment of Law No. 40 Article 74 of 2007 concerning Limited Liability Companies, In Indonesia, companies that carry out their business related to or in the field of natural resources are required to carry out social and environmental responsibilities. Therefore, the company is also obliged to disclose environmental social responsibility.The Company Performance Rating Assessment, known as the Corporate Performance Rating Rating Program is a government effort 
carried out by the Ministry of the Environment to encourage companies to manage the environment in a better way through reputation or image incentives for companies that have good environmental management performance and reputation disincentives. or the image of companies with poor performance [10]. Performance rating system The Company Performance Rating Program includes ranking companies in five colors which will be scored consecutively with the highest score of 5 for gold, 4 for green, 3 for blue, 2 for red, and the lowest score of 1 for black.

\section{Financial performance}

To meet the interests of its members, the company as a form of organization generally has certain goals to be achieved. Success in achieving the goals that have been set is an achievement for the company, especially management. One way that can be done by the management to achieve the goals set by the company and also to fulfill its obligations to investors is an assessment of the company's financial performance. In providing an overview of the financial position of a company, it can be seen from the company's financial performance as measured by financial statements issued periodically. Assessment of the achievement or performance of a company is measured because it can be used as a basis for decision making both internal and external parties [3].The financial performance of a company can be measured using financial ratios. Financial ratios are the most frequently used analytical tools. Sucipto [11] states that financial ratios relate various estimates contained in financial statements so that the financial condition and results of operations of a company can be interpreted. Financial ratios are designed to analyze or evaluate financial statements that contain data about a company's position and company operations.

Financial statement analysis is the beginning of the future when viewed from the perspective of investors, while for management it is useful to help anticipate future conditions and become the starting point for planning actions that will affect the course of future events [3].Pujiasih [3] explains that financial performance can be improved through the disclosure of Corporate Social Responsibility (CSR), with the idea that the market will give a positive appreciation as indicated by an increase in the company's stock price. Merawati [12] also revealed that Good Corporate Governance (GCG) moderates the effect of environmental performance on financial performance. Darwin [13] explained that concern for the environment is also one of the factors that affect financial performance. Concern for the environment arises due to encouragement from outside parties, including: the government, stakeholders, and consumers. There are many factors that affect the company's financial performance, but the factors that currently greatly affect the company's financial performance are environmental performance, because currently the company is required to be responsible for the impact caused by the company's activities in production. Disclosure of good environmental performance makes the company's existence in carrying out company activities accepted by the community so that it can realize good financial performance [3]. 


\section{Good Corporate Governance (GCG)}

The Cadbury Committee defines corporate governance as a set of rules that define the relationship between shareholders, managers, creditors, government, employees, and other interested parties both internally and externally with respect to their rights and responsibilities [15]. Meanwhile, Sulistyanto [2] states, definitively good corporate governance is defined as a system that regulates and controls the company so that the company creates added value for all stakeholders. Hanifah [14] stated that the objectives of GCG are as follows:

1. To reduce the gap between parties who have an interest in a company (majority shareholders and other shareholders).

2. Increase the confidence of investors in making investments.

3. Reduce the cost of capital.

4. Convince all parties of the legal commitment in managing the company.

5. Value creation for the company includes relationships between stakeholders (creditors, investors, company employees, bondholders, and the government) to create added value for stakeholders.

\section{Corporate Social Responsibility (CSR)}

Corporate Social Responsibility or social responsibility is an organizational obligation that not only provides good goods and services for the community, but also maintains the quality of the social and physical environment, and also contributes positively to the welfare of the community in which they are located [14]. According to Hackston and Milne [16], corporate social responsibility is the process of communicating the social and environmental impacts of an organization's economic activities to special interest groups and to society as a whole.Paul [17], argues that a company's CSR activities are those that go beyond compliance with environmental or social regulations, giving rise to the perception or reality that the company is advancing a social goal. According to Darwin [13] corporate social responsibility is a mechanism for an organization to voluntarily integrate environmental and social concerns into its operations and interactions with stakeholders, which goes beyond the organization's legal responsibilities.

Suharto [18] argues that Corporate Social Responsibility is a business operation that is committed not only to increasing the company's profits financially, but also to the socio-economic development of the region in a holistic, institutionalized and sustainable manner.Based on the explanation above, it can be concluded that corporate social responsibility is the company's obligation to always balance the welfare of the owner and the welfare of the social environment, not only providing goods and services for the community. From the various definitions of corporate social responsibility, there is one thing in common that CSR cannot be separated from the interests of the company's shareholders and stakeholders. They are the owners of the company, the employees, the people of the country and the environment. This concept was later defined by John Elkington as the triple bottom line, namely profit, people, 
and planet. The point is that the purpose of CSR must be able to increase company profits, improve employee welfare, and the community, as well as improve environmental quality [19].

Jogiyanto [5;20], divides the area of corporate social responsibility into three levels, namely:

1) Basic responsibility is a responsibility that arises because of the existence of the company, for example the obligation to pay taxes, obey the law, meet job standards, and satisfy shareholders.

2) Organizational Responsibility shows the company's responsibility to meet the changing needs of stakeholders such as workers, consumers, shareholders and the surrounding community.

3) Social Responsibility describes the stage when the interaction between business and other forces in society is so strong that the company can grow and develop sustainably.

Corporate social responsibility is disclosed in a report called sustainability reporting. Sustainability reporting is reporting on economic, environmental and social policies, the influence and performance of organizations and their products in the context of sustainable development. Sustainability reporting includes reporting on economic, environmental and social influences on social performance on organizational performance [20].Regarding the implementation of CSR, according to Suharto [18] companies can be grouped into several categories. Although it tends to simplify reality, this typology describes the company's ability and commitment in carrying out CSR. Categorization can motivate companies in developing CSR programs. It can also be used as a mirror and guideline to determine the right CSR model. Using two approaches, there are at least eight categories of companies. The ideal company has reformist and progressive categories. Of course, in reality, these categories could be intertwined.Categorization of companies based on the proportion of profits and the size of the CSR budget is divided into four types of companies.

The four types are (1) minimalist companies, in this type companies have low profits and CSR budgets, small and weak companies are usually included in this type, (2) economical companies, in this type the company has high profits but its CSR budget low, in other words large companies but stingy in issuing CSR budgets, (3) humanist companies, in this type even though the company's profits are low, the proportion of CSR budgets is relatively high, which is better known as generous or kind companies, (4) reformist companies, in this type the company has a high profit and CSR budget, this company views CSR not as a burden,Riyadi [21] states that there are two perspectives on the existence of CSR. These two perspectives do not just appear, but emerge from two perspectives on the role of business in society. The first view, the "classical view", which is based on neoclassical economic theory, sees the role of business in society as purely profit seeking, i.e. profit for shareholders. This perspective is also known as the "shareholder perspective". In contrast, the 
"stakeholder view", which is based on stakeholder theory, holds that companies have social responsibilities. Social responsibility requires companies to consider the interests of all parties affected by their actions.

\section{METHODS}

This study is a quantitative study and uses secondary data derived from the annual reports of companies listed in the IDX30 index for the period February-April 2021 on the Indonesia Stock Exchange. This study uses 30 companies according to the number of companies included in the IDX30 list as research objects with the reason to find out and prove whether IDX30 companies that are included in the company index category that are considered good on the Indonesia Stock Exchange are able to prove that their environmental performance and financial performance are can be said to be good with the existing governance in each company [24;25].

The data required are environmental performance, financial performance, Good Corporate Governance, and disclosure of Corporate Social Responsibility. The data was obtained from the official website http://www.idx.co.id and a copy of the Decree of the Minister of Environment and Forestry of the Republic of Indonesia Number SK. SK.1049/MENLHK/SETJEN/PKL.4/12/2019 concerning the results of the assessment of the company's performance rating in environmental management for 2018-2019.

\section{RESULT AND DISCUSSION}

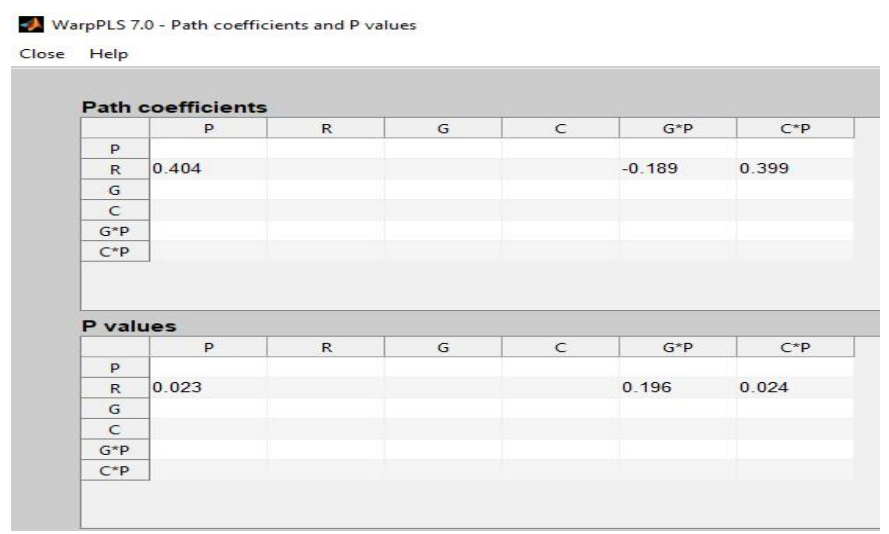

Fig 1. Hypothesis Test Results

\section{The Effect of Environmental Performance on Financial Performance}

The test results in this study state that environmental performance has a significant influence on financial performance. This can be seen from the P Values of $0.023<0.05$. These results are reflected in the sample of companies that have a good CPRP rating because environmental performance can be an added value in the eyes of consumers. The results of this study are in accordance with the results of Christian research [22].The benefits derived from environmental performance are stated by 
Pflieger [9] who says that environmental conservation efforts by companies will provide a number of benefits, including the interests of shareholders and stakeholders on company profits caused by responsible environmental management according to public perception. The amount of information disclosed by the company depends on the number of activities carried out by the company, including environmental activities. This illustrates the company's attitude of transparency in carrying out its responsibilities and interests in the activities carried out during the production process, so that consumers know how much responsibility and concern the company has for the environment.

\section{Good Corporate Governance as Moderating Relationship Between} Environmental Performance and Financial Performance

The results of the test of the effect of environmental performance on financial performance moderated by Good Corporate Governance were rejected. This can be seen from the $\mathrm{P}$ Values of $0.196>0.05$. This proves that good corporate governance in the IDX30 company has no effect on improving the quality of environmental performance and financial performance in terms of return on assets. Shows that the disclosure of good corporate governance does not have any impact on environmental performance and financial performance because environmental performance is a responsibility that must be carried out regardless of corporate governance and also does not have any impact on asset control in increasing profitability because consumers are not affected by reports corporate governance.Good Corporate Governance is able to influence stakeholders or stakeholders as Sulistyanto's opinion [2] which states, definitively good corporate governance is defined as a system that regulates and controls the company so that the company creates added value for all its stakeholders.

\section{Corporate Social Responsibility as Moderating Relationship Between}

\section{Environmental Performance and Financial Performance}

The test results of the influence of environmental performance on financial performance moderated by Corporate Social Responsibility are accepted. This can be seen from the P Values of $0.024<0.05$. This shows that the company's activities in carrying out social responsibility have a significant impact on success in increasing profitability to get a good return on assets because it supports the company's image in the eyes of the public. In addition, CSR is also related to other economic problems such as Suharto's opinion [18] that Corporate Social Responsibility is a business operation that is committed not only to increasing company profits financially, but also to the socio-economic development of the region in a holistic, institutionalized and sustainable manner.

Meanwhile, the impact of CSR on environmental performance can be seen when the company carries out one of the programs such as doing reforestation together and distilling clean water for local residents as well as various other ways to preserve the environment as stated in the regulation of law number 40 of 2007 concerning limited liability companies. the provision of CSR is only limited to companies or 
companies whose business activities are related to natural resources (SDA). Good CSR implementation has become a must for companies that want to be more advanced, as stated by Paul [17] who argues that a company's CSR activities are those that exceed compliance with environmental or social regulations

\section{CONCLUSION}

Based on the results of this study, the following conclusions can be drawn:

1) Environmental performance affects financial performance. This can be seen from the $\mathrm{P}$ Values of $0.023<0.05$

2) Good Corporate Governance does not moderate the relationship between environmental performance and financial performance. This can be seen from the $\mathrm{P}$ Values of $0.196>0.05$

3) Corporate Social Responsibility moderates the relationship between environmental performance and financial performance. This can be seen from the $\mathrm{P}$ Values of $0.024<0.05$.

Based on the results obtained in this study, the recommendations that can be given are:

1) On average, IDX30 companies have environmental performance with a fairly good PROPER score and some have received the highest score, namely a gold rating. All of that should be improved again in order to make the company's image even better in the eyes of customers and stakeholders in order to get a better return on assets.

2) Companies should continue to follow PROPER continuously and sustainably with a company attitude that is always honest in carrying out good environmental performance, lest there be companies that bribe to get PROPER scores or good environmental performance.

3) It is hoped that there will be no more companies that have a number of independent boards of commissioners and boards of commissioners that differ greatly, because this can have a negative impact because there are specific tasks that should be shared and not duplicated, such as supervision and inspection in managing the company.

4) In carrying out CSR, companies should focus more on villages that are very underdeveloped to help these villages be more advanced than before because almost all parts of Indonesia still have villages that still need social assistance.

5) For further researchers, it is recommended to use other measurement proxies to measure the variables that exist in this study, such as using the ratio of Return on Equity (ROE), Profit Margin on Sales, or earnings per share as a proxy for calculating profitability for financial performance variables, while for measure environmental performance, can use the Indonesian Environmental Reporting Index (IERI). Or compare between Proper and IERI in measuring financial performance. 


\section{REFERENCES}

[1] Lako, Andreas. 2011. CSR Deconstruction \& Business and Accounting Paradigm Reform, Page:3. Jakarta: Erlangga.

[2] Sulistyanto, Sri. 2008. Earnings Management: Theory and Empirical Models. Jakarta: Grasindo.

[3] Praise. 2013. The Effect of Environmental Performance on Financial Performance With Corporate Social Responsibility (CSR) as an Intervening Variable. Essay. Semarang State University. Semarang.

[4] Hery, 2010. Portrait of the Internal Audit Profession (in Leading Private \& StateOwned Companies). Bandung: Alphabeta.

[5] Jogiyanto. (2008). Portfolio Theory and Investment Analysis. Fifth Edition, BPFE. Yogyakarta.

[6] Lankoski, L. 2000. Determinants of Environmental Profit: An Analysis of The FirmLevel Relationship between Environmental Performance and Economic Performance. Finland: Doctoral Dissertation. Institute of Strategy and International Business, Helsinki University of Technology.

[7] Suratno, Darsono, and S. Mutmainah. 2006. Effect of Environmental Performance on Environmental Disclosure and Economic Performance. IX Padang National Accounting Symposium. August 23-26

[8] Lucky, J. Budi. 2012. Corporate social responsibility. Jakarta: Sinar Graphic.

[9] Pflieger, J., F. Matthias, T. Kupfer, and P. Eyerer. 2005. The contribution of life cycle assessment to global sustainability reporting of Organization. Management of Environmental Quality Journal, Vol. 16, No. 2, pp. 167-179.

[10] Leimona, Beria and A. Fauzi. 2008. CSR and Environmental Preservation (Managing Impacts: Positive and Negative). Jakarta: Indonesia Business Links.

[11] Sucipto. 2003. Financial Performance Assessment. USU Digital Library. Medan.

[12] Merawati, L. Komang. 2015. The role of the Good Corporate Governance mechanism in the relationship between Environmental Performance and Financial Performance. Journal of Management \& Accounting STIE Triatma Mulya, Vol. 21, No. 2, p. 157 168.

[13] A. Darwin. 2004. Implementation of Sustainability Reporting in Indonesia. National Accounting Convention V. Advanced Professional Program. Yogyakarta.

[14] Hanifah, Riziki. 2010. The Effect of Good Corporate Governance on Earnings Management in Manufacturing Companies Listed on the Indonesia Stock Exchange. Essay. Semarang: Semarang State University.

[15] Emirzon, Joni. 2006. Regulatory Driven in the Implementation of Good Corporate Governance Principles in Companies in Indonesia. In Sriwijaya Journal of Management and Business Volume 4 No. December 8, 2006. Sriwijaya University.

[16] Hackstone, David and MJ Milne. 1996. Some Determinant Of Social and Environmental Disclosures in New Zealand Companies. Accounting, Auditing, and Accountability Journal. Vol. 9, No. 1, PP. 77-108.

[17] Paul, CJ Morrison. 2006. Corporate Social Responsibility and Economic Performance. Department of Agricultural and Resource Economics, University of California.

[18] Suharto, Eddie. 2008. Corporate Social Responsibility: What is and Benefits For Corporate. www.policy.hu/suharto. 
[19] Titisari, K. Hendra. 2009. Corporate Social Responsibility (CSR) and Company Performance, Management Dynamics, Vol. 1, No. 1, November. Surakarta: FE UNIBA.

[20] Anggraini, Fr. RR 2006. Disclosure of Social Information and Factors Affecting Disclosure of Social Information in Annual Financial Reports. IX National Accounting Symposium. field. August 23-26.

[21] Riyadi, E. Sius. 2008. Theoretical Foundation for Corporate Social Responsibility: from Shareholders (Shareholders) to Stakeholders (Stakeholders). Dignitas Volume V, No. 11.

[22] Kristen, L. Alin and FWS Werastuti. 2020. The Effect of Environmental Performance and Social Performance on Financial Performance With Good Corporate Governance as Moderating Variable, Vol 11, No 03. Indonesia: Ganesha Singaraja University of Education.

[23] Miladiasari, et al. 2020. The Effect Of Environmental Performance And Environmental Fees On Financial Performance With Good Corporate Governance As Moderated Variables. Accounting Research Festival. Faculty of Economics UIN Walisongo Semarang.

[24] Sugiyono. 2017. Quantitative Research Methods. Bandung: Alphabeta.

[25] Sugiyono. 2018. Quantitative, Qualitative, and R\&D Research Methods. Bandung: Alphabeta.

[26] Tessa, C and Harto, P. 2016. Fraudulent Financial Reporting: Testing the Theory of Pentagon Fraud in the Financial and Banking Sector in Indonesia. Lampung. XIX National Accounting Symposium.

[27] Tahjono, Mazda. 2013. The Effect of Environmental Performance on Company Value and Financial Performance. Journal of Economics, Vol. 4, No. 1.

[28] Vivianita, Alfa and F. Nafasati. 2018. The Effect of Environmental Performance on Financial Performance With Corporate Governance as Moderating Variable, Vol 03, No 01. Semarang: Semarang University.

[29] Sudaryanto. 2011. The Effect of Environmental Performance on Financial Performance With CSR as an Intervening Variable. Essay. Diponegoro University. Semarang.

[30] Setyaningsih, R. Dewi. 2016. The Effect of Environmental Performance on Financial Performance With Corporate Social Responsibility as Moderator, Vol 05, No 04. Surabaya: Indonesian College of Economics (STIESIA).

[31] Sholihin, Mahfud \& D. Ratmono. 2013. SEM-PLS analysis with Ward PLS 3.0 (Ed 1), AndiOffset, CV Andi Offset, Yogyakarta.

[32] Ja'far, SM and DA Arifah. 2006. The Influence of Environmental Management, Proactive Environmental Management and Public Environmental Performance Environmental Reporting. IX National Accounting Symposium. field.

[33] Januarti, Indira and D. Aprianti. 2005. Effect of Corporate Social Responsibility on Financial Performance. Maksi Journal, Vol. 5, No.2, Pages 227 - 243. Semarang: Faculty of Economics, Diponegoro University.

[32] Rahmawati, Ala. 2012. The Effect of Environmental Performance on Financial Performance with CSR as an Intervening Variable. Thesis S1 Faculty of Economics, University of Diponegoro. 